\title{
KELAPARAN DAN PEMBANGUNAN : STUDI KASUS INDIA
}

\section{Ita Mutiara Dewi ${ }^{1}$}

\section{Abstrak}

Kelaparan bukan merupakan hal yang baru dalam dunia manusia, bahkan salah satu indikator untuk mengukur kesejahteraan manusia adalah tersedianya bahan makanan yang cukup. Artikel ini akan membahas salah satu kasus kelaparan yang terjadi di dunia khususnya di India. Negara tersebut dewasa ini cukup terkenal dengan industri film dan teknologi informasi bahkan dapat mengembangkan energi nuklir, namun di sisi lain angka kemiskinan dan kelaparan cukup tinggi. Oleh karena itu, akan dipaparkan faktor penyebab masalah kelaparan dan kegagalan kebijakan pemerintah India dalam menangani masalah kelaparan yang dapat dikaitkan dengan situasi ekonomi dan politik domestic dan internasional, serta solusi yang lain yang memungkinkan dapat diterapkan yaitu dalam kerangka politik ekonomi islam.

Kata Kunci: kelaparan, pembangunan, politik-ekonomi

\section{PENDAHULUAN}

Menurut Wikipedia, kelaparan adalah suatu kondisi di mana tubuh masih membutuhkan makanan, biasanya saat perut telah kosong baik dengan sengaja maupun tidak sengaja untuk waktu yang cukup lama. Kelaparan adalah bentuk ekstrim dari nafsu makan normal. Istilah ini umumnya digunakan untuk merujuk kepada kondisi kekurangan gizi yang dialami sekelompok orang dalam jumlah besar untuk jangka waktu yang relatif lama.

Sejarah telah mencatat bahwa di dunia ini telah terjadi beberapa kasus angka kelaparan yang cukup besar. Pada tahun 1769 - 1770, 10 juta orang meninggal akibat banjir yang menyebabkan kelaparan di India dan diperkirakan sekitar 10 juta penduduk Cina Utara meninggal akibat kelaparan

\footnotetext{
${ }^{1}$ Staf Pengajar Faku ltas Ilmu Sosial dan Ekonomi Universitas Negeri Yogyakarta
} 
karena kondisi perang pada tahun 1877 - 1878. Pada 1943 sekitar 3 sampai 5 juta orang meninggal di provinsi Henan, Cina sebagai hasil kelaparan dalam Perang dunia II ( 1939-1945). Pada tahun 1943, India dikenal dengan kelaparan dalam angka yang tinggi di daerah Bengal (famine of Bengal). Pada abad ke 20 di Swahili, Afrika telah diserang kelaparan selama beberapa kali. Amerika Selatan dan Utara secara relatif bebas dari kelaparan besar-besaran, sedangkan di Eropa dilanda kelaparan pada saat tertentu saja terutama pada masa Perang dunia II yang memakan korban ratusan ribu orang meninggal (Latham, 2005).

Menurut Food and Agriculture Organization (FAO), jumlah orang yang kurang gizi (malnutrisi) pada tahun 2000-2002 yaitu India 250,4 juta jiwa, Cina 142,1 juta jiwa, Bangladesh 42,5 juta jiwa, Republik Demokratik Kongo 35,5 juta jiwa, Ethiopia 31,3 juta jiwa, Pakistan 29,3 juta jiwa, Filipina 17,2 juta jiwa, Tanzania 15,6 juta jiwa, Brazil 15,6 juta jiwa, Vietnam 14,7 juta jiwa, Indonesia 12,6 juta jiwa. Dari data statistik diatas dapat disimpulkan bahwa peringkat pertama jumlah kelaparan yang berdampak pada malnutrisi diduduki oleh India. Memang dapat dikatakan sebagai suatu hal yang kontras dimana India diprediksi menjadi kekuatan baru pada tahun 2020, di satu sisi ekonomi India sekarang ini cukup maju karena industri teknologi informasi, industri baja, dan filmnya, di sisi lain banyak yang menderita kemiskinan dan kelaparan. Oleh karena itu tulisan ini akan mempelajari faktor-faktor penyebab kelaparan, bagaimana kebijakan ekonomi India di bidang pertanian dan perdagangan,serta dan solusinya.

\section{SEKILAS PROFIL INDIA}

India merupakan negara di kawasan Asia Selatan yang berbatasan dengan barat laut Pakistan, utara dengan Cina, Tibet, Nepal dan Bhutan, timur dengan Burma, tenggara, selatan, dan barat daya dengan Samudera Hindia. Luas wilayah India yaitu 31,65,569 km persegi (Grover : 2000). Ekonomi India merupakan tiga terbesar di dunia dihitung dari purchasing power parity (PPP) dengan Gross Domestic Product (GDP) AS \$3.666 trilyun. Jika diukur dengan 
nilai tukar dolar, merupakan nomor sepuluh di dunia dengan GDP AS \$902.0 milyar (2007). India merupakan negara kedua tercepat dalam pertumbuhan ekonomi di dunia, dengan pertumbuhan GDP 9,2 \% pada akhir triwulan kedua 2006 - 2007. Bagaimanapun populasi India yang besar menghasilkan pendapatan per kapita $\$ 3400$ berdasarkan PPP and $\$ 714$ berdasarkan nominal. World Bank mengklasifikasikan India sebagai negara dengan low-income economy (http:/ / www.wikipedia.org).

Sektor penting dalam perekonomian India meliputi pertanian, kerajinan tangan, tekstil, bahan kimia, baja, semen, pertambangan, petroleum, mesinmesin, software dan berbagai sektor jasa. Meskipun dua pertiga dari angkatan kerja India menghabiskan waktu hidunya secara langsung maupun tidak langsung di bidnag pertanian, jasa merupakan sektor yang berkembang dan memainkan peranan penting. Sedangkan di era digital ini, sejumlah besar masyarakat muda dan terdidik yang fasih berbahasa Inggris secara gradual merubah India menjadi tujuan back office bagi perusahaan dunia dalam customer service dan technical support. India merupakan eksportir utama highly-skilled workers dalam software dan teknik.

Sedangkan populasi penduduk yang berada di bawah garis kemiskinan adalah $22 \%$. India menghadapi populasi yang berkembang pesat dan tantangan mengurangi kesenjangan ekonomi dan sosial. Kemiskinan dan kelaparan merupakan masalah serius meskipun telah berkurang jumlahnya secara signifikan sejak kemerdekaan terutama dalam era revolusi hijau dan reformasi ekonomi.

Setiap negara tentunya memiliki arti penting di bidang politik dan ekonomi, khususnya yang dibahas disini adalah berkaitan dengan pertumbuhan ekonomi dan perdagangan. Pada masa kolonial di tahun 1793, diberlakukan Land Settlemet Act oleh perusahaan Hindia Timur. Pada tahun 1820, ekonomi India berkontribusi $16 \%$ dari pendapatan dunia, nomor dua setelah Cina. Tahun 1870, di bawah kepemimpinan raja Inggris, ekonomi India menjadi 12,2\% dari pendapatan dunia. Tahun 1913 ekonomi India menjadi 7,6 \% dari 
pendapatan dunia. Tahun 1943, dikenal sebagai era kelaparan di Bengali. Tahun 1952, ekonomi India menjadi 3,8 \% dari pendapatan dunia. Tahun 1973 ekonomi India \$494.8 juta yang berkontribusi 3,1 \% dari pendapatan dunia. Tahun 1980 - 1991, India menerapkan kebijakan ekonomi tertutup. Tahun 1991 diterapkan liberalisasi ekonmomi oleh PM P. V. Narasimha Rao menteri keuangan Manmohan Singh sebagai respon atas krisis ekonomi makro. Tahun 1998 ekonomi India bernilai \$1,702.7 juta atau 5\%dari pendapatan dunia. Tahun 2005, ekonomi India bernilai \$3,815.6 juta (berdasarkan purchasing power parity) atau $6.3 \%$ dari pendapatan dunia, keempat terbesar dalam GDP riil

\section{FAKTOR-FAKTOR PENYEBAB KELAPARAN DI INDIA}

Dalam teori klasik, kelaparan sesuai dengan apa yang dikemukaan oleh Thomas Robert Malthus dalam The Principle of Population 1798, yang memfokuskan pada pertumbuhan jumlah penduduk dan persediaan makanan. Teori tersebut menyatakan pertumbuhan populasi yang secara alami melampaui pertumbuhan produksi makanan, menyebabkan penurunan per kapita ketersediaan makanan yang signifikan, sampai titik dimana kelaparan, atau beberapa bencana lain yang terjadi secara drastis akan mengurangi populasi manusia kepada suatu tingkatan yang mana dapat ditopang oleh makanan yang tersedia. Tetapi teori ini sekarang jarang digunakan karena melupakan pertumbuhan teknologi untuk pelipatgandaan pangan.

Menurut Encarta Encyclopedia, penyebaran kelaparan dapat disebabkan oleh kemiskinan, distribusi makanan yang tidak efisien, atau populasi yang meningkat di suatu wilayah tidak berbanding lurus dengan produksi makanan. Kelaparan juga dapat disebabkan oleh: (1) kondisi alam seperti banjir, gempa bumi, kegagalan panen akibat wabah serangga dan penyakit tanaman; (2) tindakan manusia sendiri mencakup perang, konflik, dan perusakan panen yang disengaja. Efek berantai dari kelaparan adalah malnutrisi protein-energi, yang menyebabkan kerentanan terhadap penyakit seperti diare, campak, TBC, infeksi yang akhirnya berujung pada kematian terutama anak-anak dan bayi. 
Menurut Institute for Food and Development Policy, sekitar 200 juta masyarakat India tengah mengalami kelaparan pada tahun 1995, tetapi India mengekspor gandum dan tepung terigu yang nilainya mencapai 625 juta dolar AS. India juga mengekspor 5 juta ton beras yang nilainya mencapai 1,3 milyar dolar AS. Baik gandum, tepung terigu dan beras, merupakan bahan makanan pokok masyarakat India (Widyamartaya, Ab. A. dan Widyanta, 2004: 45).

Berdasarkan fakta di atas, penjelasan WHO dalam Determinant of Malnutrition 2001 cukup sesuai dalam menelusuri faktor penyebab kelaparan di India, dimana dinyatakan bahwa masalah kelaparan adalah bahwa pangan tidak diproduksi dan tidak disalurkan secara layak dan adil. Selain itu, seringkali, orang-orang miskin hanya berdiri dalam diam dengan tangan kosong dan juga perut kosong. Mereka juga hanya terpaku memandang hasil panenannya dan hasil bumi yang berlimpah-limpah diekspor demi uang tunai semata. Dalam jangka pendek, hal itu hanya akan menguntungkan segelintir orang saja sementara dalam jangka panjang akan sangat merugikan banyak orang. Kelaparan adalah persoalan distribusi yang timpang (maldistribution) dan masalah ketidakadilan, bukan masalah kekurangan pangan. Itulah sebabnya mengapa meskipun ada panen berlimpah, kelaparan tetap terjadi. Meskipun ada kemajuan, kemiskinan pun tetap saja berlangsung.

Senada dengan hal tersebut, Departemen Pertanian AS dalam Food Security Assessment 1999 menyatakan bahwa fokus utama kebijakan keamanan pangan internasional adalah memperbesar ketersediaan pangan, sementara persoalan distribusi pangan yang timpang yang disebabkan oleh kerawanan pangan (food insecurity) cenderung diabaikan. Selain masalah distribusi, kelaparan yang terjadi terutama di kalangan petani terjadi karena petani kehilangan tanah, penghapusan subsidi pupuk, dan sebagainya yang akan dijelaskan lebih terperinci dalam kebijakan pertanian dan perdagangan India..

\section{KEBIJAKAN PERTANIAN DAN PERDAGANGAN DI INDIA}


Ekspor India mengalami stagnasi selama lima belas tahun setelah kemerdekaan, pada masa dominasi produksi teh, jute dan kapas, permintaan cenderung inelastis. Bagaimanapun produk pertanian merupakan sektor yang cukup penting dalam perdagangan di India, dimana pada tahun 1986 India menjadi pengekspor utama teh yaitu 26,6\%, peringkat keempat dalam beras yaitu 5,2 \%, urutan keempat dalam tembakau yaitu 4,6 \%. Impor dalam waktu yang sama mencakup mesin-mesin, bahan baku dan peralatan, dimana pada saat itulah industrialisasi mulai terjadi. Sejak liberalisasi pada tahun 1991, nilai perdagangan internasional India menjadi meluas dan meningkat sampai Rs. 63,080,109 crores pada tahun 2003 - 2004 dari Rs.1,250 crores pada 1950-51. Rekan utama perdagangan India adalah Cina, AS, Jepang dan Uni Eropa. Nilai ekspor pada bulan Agustus 2006 adalah AS \$10.3 milyar meningkat sampai 41,4 $\%$ dan impor $\$ 13.87$ meningkat 32,16\% dari tahun sebelumnya.

\section{Tabel 1. Komposisi total produksi (million tonnes) panen bahan makanan}

\section{komersial 2003 - 2004}

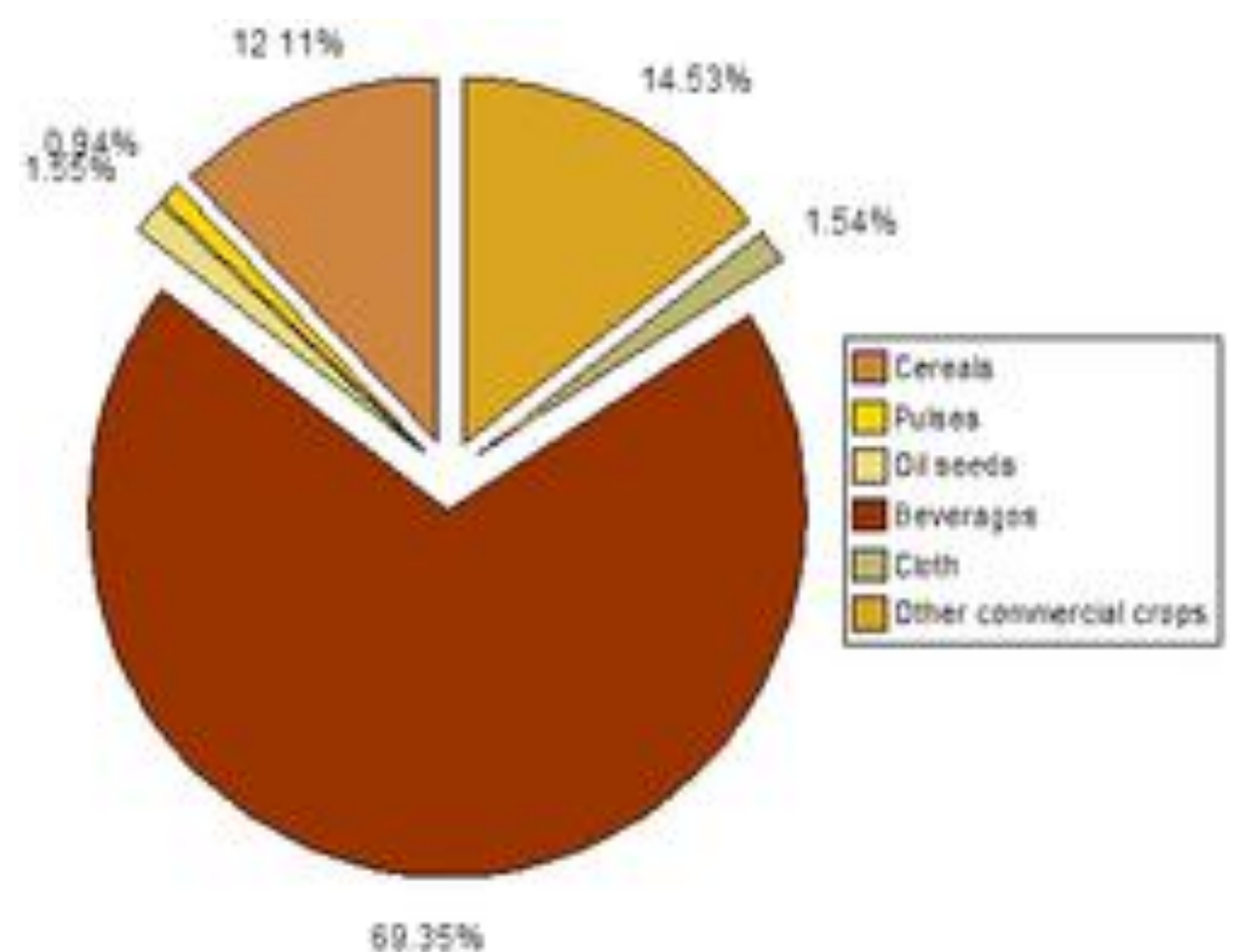

Year Cereals Rice Wheat Coarsegrains Pulses 
2001-02 199,480,000 93,340,000 72,770,000 33,370,000 $13,370,000$

2004-05 192,730,000 87,800,000 73,030,000 31,880,000 $\quad 13,670,000$

Sumber: Department of Food and Public Distribution with figures in tonnes

Perdagangan ke luar negeri atau ekspor-impor dianggap sebagai sesuatu yang penting dalam teori klasik maupun neo-klasik yang berkaitan dengan pertumbuhan ekonomi suatu negara. Dengan meningkatnya perdagangan, diharapakan dapat menambah pemasukan devisa negara sehingga pertumbuhan ekonomi menjadi tinggi, mengurangi angka kemiskinan dan kelaparan. Sebagai representasi dari teori klasik yaitu prinsip keunggulan komparatif ala Adam Smith, yang menegaskan bahwa suatu negara harus memproduksi dan mengekspor jenis-jenis barang yang biaya relatifnya rendah. India melakukan perdagangan dengan negara lain, atas dasar teori tersebut agar lebih terspesialisasi dalam produk pertanian tertentu sebagai keunggulan absolut.

Negara-negara berkembang termasuk India melakukan perdagangan karena mengganggap teori perdagangan neo-klasik sebagai sesuatu yang signifikan (Todaro, $2000: 85)$ :

1. Perdagangan merupakan faktor penting guna merangsang pertumbuhan ekonomi di setiap negara. Perdagangan akan memeperbesar kapasitas konsumsi suatu negaar, meningkatkan output dunia, serta menyajikan akses ke sumber-sumber daya yang langka dan pasar-pasar internasional yang potensial untuk berbagai produk ekspor, yang mana jika tidak tersedia, maka negara-negara miskin tidak akan mampu mengembangkan kegiatan dan kehidupan perekonomian nasionalnya;

2. perdagangan cenderung mempromosikan pemerataan atas distribusi pendapatan dan kesejahteraan domestik internasional. Hal ini berlangsung melalui suatu proses penyamaan harga-harga faktor produksi di semua negara, peningkatan pendapatan riil setiap negara yang terlibat dalam 
kegiatan-kegiatan perdagangan internasional, serta memacu efisiensi pemanfaatan sumber daya dunia secara keseluruhan (misalnya, dengan meningkatkan upah relatif di negara-negara yang kaya akan tenaga kerja dan menurunkan upah di negara-negara yang kurang tenaga kerja);

3. perdagangan dapat membantu semua negara dalam menjalankan usahausaha pembangunan mereka melalui promosi serta pengutamaan sektorsektor ekonomi yang mengandung keunggulan komparatif baik itu berupa ketersediaan faktor-faktor produksi tertentu dalam jumlah yang melimpah, atau keunggulan efisiensi alias produktivitas di setiap negara

4. jika perdagangan dunia yang bebas benar-benar tercipta, maka harga dan biaya-biaya produksi internasional akan mampu berfungsi sebagai determinan pokok mengenai seberapa banyak sebuah negara harus berdagang dalam rangka memaksimalkan kesejahteraan nasionalnya. Setiap negara akan bertindak sesuai dengan prinsip keunggulan komparatif dan tidak akan mencoba-coba mengganggu beroperasinya mekanisme pasar bebas

5. untuk mempromosikan pertumbuhan ekonomi dan pembangunan yang pada umumnya, setiap negara perlu merumuskan dan menerapkan kebijakan-kebijakan berorientasi ke lingkungan internasional. Dalam semua kemandirian yang didasarkan pada isolasi, baik yang penuh maupun hanya sebagian, tetap saja secara ekonomi akan lebih rendah nilainya daripada partisipasi ke dalam perdagangan dunia yang benar-benar bebas tanpa batasan atau hambatan apapun.

India memutuskan untuk bergabung dalam General Agreement on Tariffs and Trade (GATT) pada tahun 1947, dan selanjutnya menjadi World Trade Organization (WTO). Bergabungnya India ke WTO, terbukti memang meningkatkan pendapatan dan perdagangan. Hal ini dapat diamati dalam tabel sebagai berikut:

Tabel 2. Dampak Liberalisasi Perdagangan Pertanian di Negara Maju terhadap Peningkatan Pendapatan Negara Berkembang 


\begin{tabular}{|c|c|c|c|c|}
\hline \multicolumn{3}{|c|}{$\begin{array}{c}\text { Peningkatan Pendapatan Akibat Liberalisasi } \\
\text { Agrobisn is }\end{array}$} & \multirow{2}{*}{$\begin{array}{c}\begin{array}{c}\text { Peningkatan } \\
\text { Agrobisnis }\end{array} \\
\text { Juta AS \$ }\end{array}$} & \multirow{2}{*}{$\begin{array}{c}\text { Perdagangan } \\
\text { (Ekspor-Impor) } \\
\%\end{array}$} \\
\hline Negara & Juta AS \$ & $\%$ & & \\
\hline Cina & $2.265,4$ & 1,5 & $3.664,3$ & 327,3 \\
\hline Indonesia & 593,6 & 1,2 & 1039,8 & 93,5 \\
\hline Malaysia & 261,3 & 2,4 & 440,3 & 22,3 \\
\hline Filipina & 238,1 & 1,4 & 394,7 & 31,0 \\
\hline Thailand & 1755,0 & 11,0 & 2873,1 & 57,2 \\
\hline Vietnam & 81,9 & 3,1 & 205,2 & 14,2 \\
\hline Bangladesh & 43,6 & 0,6 & 112,9 & 16,8 \\
\hline India & 1129,4 & 1,1 & 1376,1 & 28,0 \\
\hline Meksiko & 980,6 & 1,9 & 1376,1 & 382,4 \\
\hline Karibia & 1531,8 & 9,5 & 2754,1 & 78,5 \\
\hline Argentina & 1833,0 & 2,8 & 2674,0 & 24,4 \\
\hline Brazil & 2258,7 & 2,5 & 4262,0 & 49,5 \\
\hline Chile & 240,8 & 2,6 & 581,0 & 20,4 \\
\hline Uruguay & 154,5 & 4,8 & 298,4 & 34,5 \\
\hline Amerika Selatan & 242,7 & 15,9 & 536,2 & 166,0 \\
\hline Timur Tengah & 1244,6 & 4,6 & 1924,9 & 17,0 \\
\hline Afrika Utara & 736,9 & 2,3 & 1224,9 & 19,1 \\
\hline Afrika Sub-Sahara & 888,6 & 2,6 & 1342,5 & 32,3 \\
\hline
\end{tabular}

Sumber : IFPRI (2003)

Keterangan: Angka-angka diatas mewakili peningkatan persentase dalam ekspor bersih. Jika ada negara mengekspor AS \$ 100 juta dan mengimpor 90 juta, ekspor bersihnya adalah AS \$ 10 juta. Jika ekspor meningkat AS \$ 10 juta, hal tersebut menunjukkan bahwa hanya ada peningkatan $10 \%$ dalam nilai ekspor tapi meningkat $100 \%$ dalam ekspor bersih

Bergabungnya India ke dalam WTO juga menyebabkan permasalahan mengingat sebagai anggota, maka terikat dengan peraturan keanggotaan 
meskipun terkadang atau seringkali merugikan. Beberapa kebijakan WTO yang dapat menyebabkan kerugian para petani yaitu:

1. Persetujuan tentang pertanian atau Agreement on Agriculture (AoA)

Persetujuan tentang pertanian adalah sistem yang mendasarkan diri pada aturan liberalisasi perdagangan di bidang pertanian. Sistem ini muncul atas desakan AS beserta sejumlah korporasi agribisnis multinasionalnya yang berusaha memaksakan suatu sistem persaingan global yang tidak seimbang di sektor pertanian domestik. Caranya yaitu dengan melumpuhkan kemampuan/ketahanan pertanian-pertanian rakyat. Upaya ini dimaksudkan agar petani tidak mampu bersaing dengan berbagai produk impor yang lebih murah. Hal ini berimplikasi pada berjuta-juta petani kecil yang tersingkir dari lahan mereka dan untuk beberapa saat kemudian terwujudlah "program penciptaan pengungsi terbesar di dunia". Dengan demikian, maksud dan tujuan korporasi global untuk menguasai pertanian semakin memperoleh jaminan.

Di India menurut perkiraan pemerintah, pada setiap tahunnya lebih dari dua juta petani kecil dan marginal harus kehilangan tanah atau menjadi terasing dari tanah mereka sendiri. Jumlah petani yang tidak memiliki lahan di wilayah pedesaan meningkat drastis selama beberapa dekade yaitu 27,9 juta pada tahun 1951 menjadi lebih dari 50 juta pada 1990-an.

Petani tersebut kehilangan lahannya karena diambil alih oleh elit pernguasa korporasi-korporasi besar. Lahan tersebut lantas digunakan untuk menanam komoditas yang laku dipasaran seperti bunga atau dijadikan lahan budidaya udang ekspor.

Banyak dari petani yang kehilangan lahan akhirnya menjadi buruh upah harian. Mereka bekerja untuk Departemen Pekerjaan Umum (Public Works Department). Mereka terpaksa bekerja sebagai kuli di jalan-jalan tol nasional, menderita karena asap beracun, panas dan debu bahkan menerima upah kurang dari AS \$ 1 per hari. Sementara ratusan ribu petani yang lain yang tergusur dari lahannya bermigrasi ke New Delhi dan Bombay. Disana mereka 
bekerja serabutan, sebagian mengirimkan anak-anaknya yang masih muda untuk bekerja di pabrik-pabrik. Ada juga yang menjadikan anak-anaknya sebagai pengemis-pengemis kecil. Menurut Bank Dunia, jumlah penduduk yang bermigrasi ini akan melampaui gabungan jumlah penduduk Inggris, Jerman dan Perancis.

Bagi petani yang tetap tinggal di tanahnya sendiri, proses korporasi pertanian telah memperbesar dan memperparah kemiskinan. Adanya ikatan kontrak baru dengan korporasi, menjadikan korporasi itu berhasil meraup sebagian besar keuntungan yang dihasilkan dari ekspor-ekspor tersebut. Misalnya saja, para petani di Punjab yang dikontrak Pepsico untuk menanam tomat hanya menerima 0,75 rupee per satu kilogram, padahal harga tomat di pasaran mencapai 2,00 rupee per satu kilogram.

Adapun tiga komponen dasar AoA yaitu Dukungan Dalam Negeri, Akses Pasar dan persaingan Ekspor

a. Dukungan dalam negeri (Domestic Support)

Alasan dibalik penentuan DS pada tahun 1986-1988 merupakan trik dari negara-negara maju untuk memperlambat pembukaan pasar dalam negeri mereka dari produk-produk pertanian negara berkembang. Karena periode tahun tersebut merupakan periode ketika proteksi dan subsidi yang diberikan pemerintah negara maju seperti Jepang, AS dan Uni Eropa pada sektor pertanian mencapai angka tertinggi dibanding periode sesudahnya. Hal ini berakibat pada liberalisasi yang dilakukan dengan DS menjadi tidak berarti. Klausul-klausul DS ikut menjadi modus kecurangan dengan melakukan manipulasi pemahaman bahwa dengan mengikis subsidi kepada para produsen, petani-petani kecil di dunia ketiga diasumsikan akan lebih kompetitif dan mampu menciptakan harga-harga yang melaporkan ongkos produksi yang sesungguhnya. Padahal sebenarnya, pasal-pasal dalam DS hanya mengarah pada sebagian kecil dari pengurangan sejumlah subsidi di bidang pertanian. Sementara itu, di berbagai subsidi tambahan yang 
dinikmati oleh korporasi agribisnis dan kepentingan perdagangan global, seperti misalnya subsidi-subsidi bagi investasi, pemasaran pupuk buatan berikut prasarananya, semua masih dibebaskan dari pengurangan subsidi. Bentuk subsidi lain yang dipraktekkan oleh negara-negara maju dengan nilai besar yaitu pembayaran langsung (direct payment) yang mendukung pendapatan petani, juga diloloskan dari klausul DS. Padahal ketentuan tersebut memungkinkan AS misalnya pada bulan Juni 2000 mengumumkan program peningkatan pembayaran langsung sebesar AS \$ 7.1 milyar kepada petani-petaninya. Masalahnya direct payment selalu bertambah besar.

b. Akses pasar (Market Access) Mekanisme kunci dalam Market Access adalah membangun perdagangan dengan rezim tarif, pengurangan tarif dan pengikatatan besarnya tarif masing-masing produk pertanian. Seluruh negara yang telah menandatangani kesepakatan tersebut harus mengubah pembatasan kuantitatif dan kebijakan non-tarif untuk impor pangan, menjadi tarif bea masuk biasa. Negara-negara sedang berkembang harus mengurangi bea masuk dan berbagai pajak lainnya atas barang-barang impor sebesar $24 \%$. Hal ini tentu saja menyebabkan harga barang impor lebih murah dibandingkan produksi sendiri. Apalagi, petani kecil dan menengah di India tidak mendapatkan subsidi pupuk karena sudah dihapus setahap demi setahap - sebagaimana ada dalam persyaratan IMF - dan naiknya harga produk lain yang berkaitan dengan sarana pertanian. Akibat keputusasaan, pada tahun 1999, lebih dari 500 petani di Andhra Pradesh, Maharashtra, Kartanataka, Punjab dan Haryana berkeras hati untuk melakukan bunuh diri.

c. Persaingan ekspor

Komitmen subsidi ekspor dimaksudkan untuk mendisiplinkan kebijakan dan tindakan pemerintah yang menyalurkan bantuan terhadap ekspor. Pengurangan subsidi ekspor bertujuan untuk mengurangi distorsi di 
pasar internasional karena diasumsikan dapat memancing persaingan yang tidak sehat antara negara pemberi subsidi dan negara pengimpor. Terdapat empat ketentuan yang berlaku dalam subsidi ekspor yaitu: (1) subsidi ekspor untuk produk spesifik tertentu harus dikurangi sesuai komitmen; (2) setiap kelebihan pengeluaran pemerintah untuk keperluan itu harus dibatasi sesuai dengan yang telah disepakati; (3) subsidi ekspor buat negara berkembang dianggap konsisten dengan Special and Different Treatment (SDT); dan (4) subsidi ekspor selain dari yang harus dikurangi itu bila dilakukan maka harus diberitahukan terlebih dahulu (Khudori, 2004: 76).

Penghapusan ekspor akan memudahkan AS dan Uni Eropa untuk menjual surplus produk pertaniannya ke pasar dunia. Meskipun liberalisasi ekonomi didasari argumen bahwa pasar-pasar pertanian negara-negara Utara akan membuka diri bagi India dan negara-negara Selatan lainnya, dalam kenyataannya ekspor India ke Eropa justru turun dari $13 \%$ menjaid $6 \%$. Salah satu alasannya adalah bahwa subsidi tinggi dan hambatan proteksi masih tetap diberlakukan secara luas di negaranegara utara.

2. TRIPs (Trade-Related Aspects of Intellectual Properties)

Merupakan perjanjian tentang hak paten, hak cipta, merek dagang, yang kemudian meluas menjadi sumber-sumber hayati. Hal ini berimplikasi pada dipatenkannya berbagai gen, sel, benih tanaman dan binatang dan dimiliki sebagai kekayaan intelektual. Di India, padi Basmapati telah dipatenkan oleh perusahaan Amerika, sehingga tidak semua petani dapat menanam, membudidayakan dan mendapatkan keuntungan dari penjualan padi tersebut.

Sebenarnya, tidak hanya WTO saja yang bertanggung jawab terhadap masalah kelaparan tetapi lembaga-lembaga internasional seperti Rockefeller Foundation, Ford Foundation, FAO, United States Department of Agriculture, (USDA), lembaga Bretton Woods, dan perusahaan multinasional yang bergerak 
di sektor industri pangan seperti Mosanto (AS), Aventis (Perancis), Syngenta, Pioneer Hi-Bred, Du-Pont (AS), De Kalb, Calgene, Phillip Morris (AS), Cargill (AS), Nestle (Switzerland), Unilever (Inggris/Netherlands), Pepsico (AS), Coca Cola (AS), Conagra (AS), RJR Nabisco (AS), Grand Metropolitan (UK), Elders IXL (Australia), Anheuser Busch (AS), BSN Group (Prancis). Perusahaanperusahaan ini bergerak mulai dari penyediaan bibit unggul, pupuk, obatobatan sampai dengan produk akhir pengolahan pasca panen. Terobosanterobosan teknologi bagi industri pangan dunia ke depan semakin menjadi perhatian perusahan tersebut (Wiryono, $2004:$ 192).

\section{RESPON MASYARAKAT TERHADAP KEBIJAKAN PEMERINTAH INDIA DAN INSTITUSI INTERNASIONAL}

Pada bulan Oktober 1993, sekitar setengah juta petani di India berkumpul di Bangalore. Mereka menyerukan perlawanan terhadap putaran Uruguay GATT dan Persetujuan Hak Kekayaan Intelektual yang terkait dengan Perdagangan (TRIPs atau Trade-Related Intellectual Property Rights Agreements)

Pada bulan Oktober - Desember 2000, lebih dari 50.000 petani berkumpul di Bangalore untuk melakukan protes menentang WTO dan penguasaan korporasi atas pertanian. Pada bulan Februari 2001, lebih dari 51.000 petani siap menghadapi aksi penangkapan oleh aparat setelah mereka tidak diizinkan bergerak menuju kota pelabuhan Mumbai untuk melakukan aksi protes menentang impor bahan pangan dan WTO

\section{USAHA DALAM MENANGANI KELAPARAN}

Selama ini pemerintah India sudah beusaha menangani kelaparan dengan berbagai cara baik langsung maupun tak langsung, yang antara lain dapat diamati sebagai berikut:

1. Kebijakan pertanian yang baik 
Pemerintah India menganggap produktivitas yang rendah di sektor pertanian disebabkan beberapa faktor:

- Buta huruf, keterbelakangan sosial ekonomi yang umum, lambatnya kemajuan dalam mengimplementasikan reformasi pertanahan dan tidak cukupnya atau tidak efisiennya servis keuangan dan pemasaran produksi pertanian

- Rata-rata ukuran kepemilikan lahan cukup sempit (kurang dari 20,000 m²) dan terjadi karena fragmentasi akibat land ceiling acts dan dalam beberapa kasus, sengketa keluarga. Kepemilikan lahan yang sempit dapat menghasilkan pengangguran tersamar dan produktivitas kerjasama yang rendah.

- Penerapan langsung dari sistem agrikultur modern dan penggunaan teknologi tidak cukup, dihambat oleh diabaikannya praktek tertentu, biaya yang tinggi dan secara tidak langsungkasus kepemilikan lahan yang sempit

- Fasilitas irigasi yang tidak cukup yang ditunjukkan oleh fakta bahwa hanya $53,6 \%$ tanah yang mendapatkan irigasi di tahun 2000 - 2001 yang menyebabkan petani hanya tergantung pada air hujan, terutama pada musim hujan. Musim hujan yang baik akan menghasilkan pertumbuhan ekonomi yang meningkat secara keseluruhan sedangkan musim hujan yang burung menyebabkan terhambatnya pertumbuhan. Kredit pertanian berasal dari NABARD yang berdasarkan undang-undnag merupakan agen pembangunan desa di subkontinen India

Oleh karena itu pemerintah India harus segera mencari solusi terhadap rendahnya produktivitas pertanian seperti dengan proteksi terhadap produk pertanian serta masalah-masalah pertanian yang disebabkan oleh WTO

2. $\quad$ subsidi langsung kepada masyarakat yang malnutrisi selama ini tentunya pemerintah India maupun LSM telah mencari cara untuk mengatasi kelaparan seperti misalnya membantu dengan 
memberikan bantuan makanan atau dana secara langsung, tetapi hal itu tidak dapat menyelesaikan permasalahan masyarakat secara keseluruhan

Akan tetapi merujuk dari akar permasalahan kemiskinan yaitu penerapan teori neoklasik salah satunya berupa perdagangan bebas yang berimplikasi pada bergabungnya India dalam WTO, maka ketika berpartisipasi dalam pertemuan dewan umum WTO, pemerintah India telah memperjuangkan suara negara-negara berkembang. India melanjutkan sikap oposisinya pada masalah tenaga kerja, lingkungan dan non-tariff barriers pada kebijakan WTO. Tetapi, sampai sekarang perjuangan India tersebut belum membuahkan hasil sehingga masalah kelaparan, kemiskinan, dan lain-lain tetap terjadi. Oleh karena itu, seharusnya negara-negara berkembang berani mengambil sikap untuk menolak kebijakan AS dan negara maju yang merugikan.

Sejak awal 1980-an, reformasi ekonomi melalui SAPs telah merusak organisasi nasional di bidang pertanian, dan mendorong lebih jauh sektor agribisnis. Hal ini disebabkan pengejaran target secara agresif oleh politik perdagangan unilateralis AS (Thomas :2001). Menurut Remy ( 1984 : 310) Politik luar negeri Amerika Serikat memiliki lima tujuan dasar yaitu:

1. National Security

2. World Peace

3. Self Government

4. Free and Open Trade

5. Concern for Humanity

Mengingat keberadaan WTO seperti halnya IMF dan WB sangat dipengaruhi AS dan negara-negara maju. Apalagi dengan pengambilan keputusan di WTO yang bersifat konsensus, maka suara negara-negara berkembang tetap tidak dipertimbangkan atau didengarkan.

Menurut ideologi pasar-bebas (neo-liberalisme), cara terbaik untuk memerangi kelaparan global dan memperbaiki ekonomi petani di negaranegara sedang berkembang adalah dengan liberalisasi perdagangan dan 
investasi, produksi untuk kepentingan ekspor dan memotong dukungan domestik (dalam negeri). Akan tetapi, berbagai perubahan kebijakan tersebut sangat menggoncang ketahanan pangan dan mata pencaharian para petani kecil di negara-negara sedang berkembang.

Sama halnya dengan pasar bebas, apa yang disebut sebagai perdagangan bebas (free-trade), ditopang oleh sekian banyak rumusan teoritis yang serba memikat. Secara umum perdagangan bebas dilengkapi oleh berbagai perangkat ilmiah dan terkesan bahwa hal itu bukan hanya dapat mampu menjamin meningkatnya efisiensi ekonomi secara keseluruhan akan tetapi juga mampu menyempurnakan alokasi sumber daya. Namun sama pula halnya dengan konsep persaingan bebas dan persaingan sempurna, perdagangan bebas dalam sosoknya yang utuh hanya ada dalam teori, dan tidak pernah hadir dalam kenyataan. Keberadaannya semakin perlu dipertanyakan mengingat dewasa ini, negara-negara dunia ketiga harus menghadapi kenyataan hubunganhubungan komersial internasional yang bukan hanya tidak sempurna, tetapi sering juga tidak adil (Todaro, $2000: 8$ ).

Beberapa hal diatas semakin menunjukkan kelemahan teori neoklasik di bidang perdagangan, bukan hanya masalah kebijakan pemerintah. Selama ini telah muncul wacana alternatif berkaitan dengan perdagangan seperti fair trade sudah sering dibahas dalam berbagai wacana sedangkan penanggulangan kelaparan, sedangkan solusi dalam perspektif islam masih jarang dibicarakan. Berikut ini intisari dari solusi masalah kelaparan, politik pertanian dan politik perdagangan dalam perspektif islam:

Rasulullah SAW telah mencontohkan saat menjadi pemimpin negara di Madinah, dimana tanggungjawabnya sebagai penguasa adalah menjamin kebutuhan pokok individual berupa pangan, sandang, dan papan. Tidak boleh ada seorang pun warga negara yang kelaparan atau terkena busung lapar, pakaiannya compang-camping, atau hidup di kolong jembatan. Mengabaikan persoalan tersebut merupakan penyimpangan dari hukum syariah, bahkan merupakan kezaliman. Pada masa Khalifah Umar bin al-Khaththab, di daerah 
strategis antara Makkah dan Syam, dibangun suatu rumah yang diberi nama Dar ad-Daqiq (Rumah Tepung). Di dalamnya tersedia berbagai macam jenis tepung, kurma, dan barang-barang kebutuhan lainnya bagi orang-orang yang sedang dalam perjalanan. Penguasa juga bertanggung jawab atas terpenuhinya kebutuhan kolektif rakyat berupa pendidikan, kesehatan, dan keamanan (Kurnia,2005: 18).

Pada dasarnya, politik pertanian dalam Islam dijalankan untuk meningkatkan produksi pertanian sehingga dapat memenuhi kebutuhan pokok masyarakat. Pilihan tatacara peningkatan produksi merupakan hal yang boleh untuk ditempuh. Untuk itu, peningkatan produksi dalam pertanian biasanya menempuh dua jalan: intensifikasi (peningkatan) dan ekstensifikasi (perluasan) (Handaka : 2005).

Intensifikasi pertanian dicapai dengan meningkatkan produktivitas lahan yang tersedia. Negara dapat mengupayakan intensifikasi dengan pencarian dan penyebarluasan teknologi budidaya terbaru di kalangan para petani; membantu pengadaan mesin-mesin pertanian, benih unggul, pupuk, serta sarana produksi pertanian lainnya. Pilihan atas teknologi serta sarana produksi pertanian yang digunakan harus berdasarkan iptek yang dikuasai, bukan atas kepentingan industri pertanian asing. Sehingga, ketergantungan pada-serta intervensi oleh-pihak asing dalam pengelolaan pertanian negara dapat dihindarkan

Dalam masalah permodalan, negara harus memberikan modal yang diperlukan bagi yang tidak mampu sebagai hibah, bukan sebagai utang. Umar bin al-Khaththab pernah memberikan kepada para petani di Irak harta dari Baitul Mal yang bisa membantu mereka untuk menggarap tanah pertanian serta memenuhi hajat hidup mereka, tanpa meminta imbalan dari mereka. Di samping itu, negara harus melindungi air sebagai milik umum dan sebagai input produksi pertanian. Karena itu, air berikut sarana irigasinya tidak boleh diswastanisasi.

Adapun ekstensifikasi pertanian dapat dicapai dengan: 
Pertama: mendorong pembukaan lahan-lahan baru serta menghidupkan tanah mati. Lahan baru dapat berasal dari lahan hutan, lahan lebak, lahan pasang-surut, dan sebagainya sesuai dengan pengaturan negara.

Kedua: setiap orang yang memiliki tanah akan diperintahkan untuk mengelola tanahnya secara optimal. Bagi siapa saja yang membutuhkan (biaya perawatan) akan diberi modal dari Baitul Mal sehingga yang bersangkutan bisa mengelola tanahnya secara optimal. Namun, apabila orang yang bersangkutan mengabaikannya selama tiga tahun, maka tanah tersebut akan diambil dan diberikan kepada yang lain. Umar bin al-Khaththab ra. pernah mengatakan, "Orang yang memagari tanah tidak berhak (atas tanah yang dipagarinya) setelah (membiarkannya) selama tiga tahun."

Sedangkan politik perdagangan islam menurut Condro (2005 : 26) berdiri atas asas sebagai berikut :

1. Asas perdagangan didasarkan pada pedagangnya, bukan komoditi.

Dalam permasalahan perdagangan, baik perdagangan domestik maupun internasional, Islam menjadikan pedagang sebagai asas yang akan dijadikan titik perhatian dalam kajian maupun hukum-hukum perdagangannya. Status hukum komoditi yang diperdagangkan akan mengikuti status hukum pedagangnya. Hukum dagang/jual-beli adalah hukum terhadap kepemilikan harta, bukan hukum terhadap harta yang dimilikinya. Dengan kata lain, hukum dagang/jual-beli adalah hukum untuk penjual dan pembeli, bukan untuk harta yang dijual atau yang dibeli.

2.Perdagangan Internasional mengikuti Politik Luar Negeri islam

Menurut pandangan Islam, status pedagang internasional mengikuti kebijakan politik luar negeri Islam. Dalam politik luar negeri Islam, negaranegara di luar Darul Islam dipandang sebagai darul harbi. Darul harbi dibagi dua, yaitu darul harbi fi'lan, yaitu negara yang secara real (de facto) sedang memerangi Islam, dan darul harbi hukman, yaitu negara yang secara de facto tidak sedang berperang dengan Islam. 
Berlandaskan pada pandangan politik luar negeri itulah, maka status pedagang dapat dikelompokkan menjadi 4:

a. Pedagang yang berstatus sebagai warga negara.

Warga negara Islam, yaitu Muslim maupun non-Muslim (kafir dzimmi), mempunyai hak untuk melakukan aktivitas perdagangan di luar negeri, sebagaimana kebolehan untuk melakukan aktivitas perdagangan di dalam negeri. Mereka bebas melakukan ekspor-impor komoditi apapun tanpa harus ada izin negara, juga tanpa ada batasan kuota, selama komoditi tersebut tidak membawa dharar.

b. Pedagang dari negara harbi hukman.

Pedagang dari negara harbi hukman, baik yang Muslim maupun yang nonMuslim, memerlukan izin khusus dari negara jika mereka akan memasukkan komoditinya. Izin bisa untuk pedagang dan komoditinya, dapat juga hanya untuk komoditinya saja. Jika pedagang dari negara harbi hukman tersebut sudah berada di dalam negara, maka dia berhak untuk berdagang di dalam negeri maupun membawa keluar komoditi apa saja selama komoditi tersebut tidak membawa dharar.

c. Pedagang dari negara harbi hukman yang terikat dengan perjanjian.

Pedagang kafir mu'âhad, yaitu pedagang yang berasal dari negara harbi hukman yang terikat perjanjian dengan Negara Islam, diperlakukan sesuai dengan isi perjanjian yang diadakan dengan negara tersebut, baik berupa komoditi yang mereka impor dari Negara Islam maupun komoditi yang mereka ekspor ke Negara Islam.

\section{d. Pedagang dari negara harbi fi'lan.}

Pedagang dari negara harbi fi'lan, baik Muslim maupun non-Muslim, diharamkan secara mutlak melakukan ekspor maupun impor. Perlakuan terhadap negara yang secara real memerangi Islam adalah embargo secara penuh, baik untuk kepentingan ekspor maupun impor. Pelanggaran terhadap embargo ini dianggap sebagai perbuatan dosa. 


\section{PENUTUP}

India hanyalah satu dari sekian negara yang mengalami kelaparan. Meskipun potensi sumber daya alam, sumber daya manusia, teknologi di India cukup besar, akan tetapi permasalahannya seperti halnya negara-negara lain, dimana di negara tersebut terdapat institusi-institusi seperti IMF, WB dan WTO yang menyebabkan negara tersebut tidak dapat menyelesaikan permasalahan dengan baik. Keberadaan institusi tersebut ternyata menyebabkan kerugian di pihak petani. Meskipun India bukanlah negara dengan penduduk mayoritas muslim, tetapi India sendiri dalam sejarah peradaban islam, pernah menjadi bagian dari wilayah pemerintahan islam sehingga terkenal dengan Taj Mahal. Dalam Islam, Khilafah Islamiyah-yang negara menerapkan islam dalam segala aspek kehidupan-harus memperhatikan peningkatan produktivitas pertanian, pembukaan lahan baru, dan penghidupan tanah mati, serta melarang terbengkalainya tanah. Di samping itu, negara harus mencegah masuknya tangan-tangan asing dalam pengelolaan bidang pertanian ini, baik lewat industri-industri pertanian asing maupun lewat perjanjian multilateral WTO. Dengan demikian, terdapat jaminan produksi yang terus berlangsung dan meningkat sehingga terjamin pula pemenuhan kebutuhan pokok masyarakat.

\section{REFERENSI}

Condro, Dwi, 2005,Perdagangan Internasional, Jurnal Al-Wa'ie 66

Grover, Verinder, 2000. Government and Politics of Asian Countries 5 : India, New Delhi: Deep and Deep Publications PVT. LTD.

Handaka, Agus M. 2005, Politik Pertanian Islam. Jurnal Al-Waie 61

Widyamartaya, Ab. A. dan Widyanta,A.B. 2004, International Forum on Globalization, Globalisasi, Kemiskinan dan Ketimpangan, Yogyakarta: Cindelaras.

Khudori, 2004. Neoliberalisme Menumpas Petani, Yogyakarta: Resist Book 
Kurnia, MR. 2005, Pertanggungjawaban Penguasa Terhadap Rakyat, Jurnal AlWa'ie 66

Latham, Michael C., Famine, 2005.Microsoft $₫$ Encarta ${ }^{\circledR}$ Reference Library 2005. (C) 1993-2004 Microsoft Corporation. All rights reserved.

Wiryono, P. 2004. Neoliberalisme dalam Sektor Industri Pangan dalam I. Wibowo dan Francis Wahono, (Ed)., Neoliberalisme, Yogyakarta: Cindelaras,

Remy, Richard C., Lary Elowitz \& William Berlin, 1984.Government in The US, New York: Mac Millan Publishing Company.

Todaro, Michael P,.2000. Pembangunan ekonomi di Dunia Ketiga, Jakarta: Penerbit Erlangga,

Thomas, Caroline, 2001. Poverty, Development and Hunger, dalam John Baylis dan Steve Smith (ed.), The Globalization of World Politics, New York: Oxford University Press.

http://www.wikipedia.org

\section{Biodata Penulis:}

Ita Mutiara Dewi, S.I.P., staf pengajar Fakultas Ilmu Sosial dan Ekonomi (FISE) Universitas Negeri Yogyakarta (UNY), telah menamatkan S-1 jurusan Ilmu Hubungan Internasional Fisipol UGM dan sekarang sedang mengerjakan tugas akhir untuk studi S-2 Ilmu Politik Konsentrasi Ilmu Hubungan Internasional HI UGM. Mata Kuliah yang diampu di FISE UNY yaitu Dasar-dasar Ilmu Politik, Sejarah Politik dan Hubungan Internasional, Sejarah dan Perspektif Global. 